\title{
Traumatic injuries in the nervous system
}

\section{Mårten Risling* , Bo-Michael Bellander and Staffan Cullheim}

Karolinska Institutet, Stockholm, Sweden

*Correspondence: marten.risling@ki.se

\section{A BRIEF HISTORY OF KAROLINSKA INSTITUTET}

Like many other countries in Europe, nineteenth century Sweden had suffered from an extensive period of wars. After a devastating Finnish war against Russia 1808-1809, the Swedish king Karl XIII decided to start a new training facility for Army surgeons. This new institute was named "Medico-Chirurgiska Institutet," but soon the prefix "Karolinska" was added. The word "Karoliner" had been used to denote soldiers during the reign of the warrior kings Karl XI and Karl XII. After 200 years of peace, this word has fortunately become more associated with a medical university.

Originally, the institute was located in central Stockholm close to the Royal castle, but it moved in the late 1940s to Solna, on the north side of the city. Karolinska institutet is now Sweden's third oldest medical school and is associated with the Karolinska University Hospital. A committee at the institute appoints the laureates for the Nobel Prize in Physiology or Medicine. Several laureates have been awarded for outstanding studies on the nervous system, including Camillo Golgi, Santiago Ramón y Cajal, Charles Scott Sherrington, Otto Loewi, Joseph Erlanger, Herbert Spencer Gasser, Andrew Fielding Huxley, Julius Axelrod, Ulf von Euler, Bernard Katz, Roger Sperry, Ragnar Granit, David Hubel, Torsten Wiesel, Arvid Carlsson, Paul Greengard, Eric Kandel, Richard Axel, and Linda Buck.

Neuroscience research has been a strong area for a substantial amount of time at both Karolinska institutet and Karolinska University Hospital. Future neurotrauma research at this location has a solid foundation to rest upon. It is impossible to name all the distinguished neuroscientists from Karolinska institutet in this editorial, but a few examples can be noted.

One early example is "Studien in der Anatomie des Nervensystems und des Bindegewebes" by Axel Key and Gustaf Retzius in the 1870s. Ulf von Euler's studies on storage mechanisms of adrenergic neurotransmitters were succeeded by the work of Nils Hillarp and his successful followers Kjell Fuxe, Tomas Hökfelt, and many others. Hökfelt is also well-known for his studies on neuropeptides, many of which had been discovered by von Euler or Viktor Mutt. Neurophysiology has a long and strong tradition with scientists like Ragnar Granit, Curt von Euler, and Sten Grillner, who demonstrated the importance of circuits for locomotion in the spinal cord. The late Håkan Persson and his associates Patrik Ernfors and Carlos Ibáñez have studied and identified neurotrophic growth factors. Jonas Frisén and Ernst Arenas have conducted pioneering work with neuronal stem cells. Lars Olson has been active in many areas, including experiments with surgical reconstruction after spinal cord lesions. The methodological development by Fritiof Sjöstrand started an era of ultrastructure research at the Department of Anatomy that provided details on the fine structure of the nervous system.

Herbert Olivecrona had an instrumental role in developing neurosurgery into a modern specialty at Karolinska institutet. After Lars Leksell's description of the gamma motor system, he continued with clinical work and became a professor of neurosurgery, succeeding Olivecrona. He developed instruments for stereotactic surgery and the Gamma Knife for non-invasive treatment of brain tumors. Thomas Carlstedt started his work on surgical replantation of avulsed spinal nerve roots at Karolinska institutet and the hospital. Sweden's largest trauma center is now located at Karolinska sjukhuset in Solna. A new modern hospital building will replace the old hospital in 2016, adjacent to new research buildings at the campus of Karolinska institutet.

\section{NEUROTRAUMA}

The seminal works of Ramon y Cajal demonstrated that on a cellular level, the central and peripheral nervous system (CNS and PNS), share many injury response patterns. He also provided a detailed description of the general lack of regeneration in the central nervous system. Furthermore, Cajal predicted the importance of neurotrophic factors and also showed a few examples of regenerative growth in the CNS. Research has not yet been able to drastically improve regeneration in the CNS, in spite of current knowledge regarding growth factors, inhibitory molecules, axon guidance mechanisms, and stem cells. Traumatic brain injuries (TBI) also face the problem of limited space inside the scull, which means that an edema or bleeding rapidly can become lethal. To the complexity of the CNS adds a complex cascade of secondary injury mechanisms. Development and testing of curative drugs is complicated due to the great variation among patients and injury patterns. The only factor that can improve this situation is more research. For obvious reasons, research must be carefully planned and significant efforts are required to ensure a good translation between experimental and clinical work.

\section{THE 200 YEAR ANNIVERSARY NEUROTRAUMA SYMPOSIUM}

The three sessions of the symposium covered a number of themes in current neurotrauma research, such as injury mechanisms and new injury models for experimental work. A couple of the lectures provided detailed information on the influence small differences in genetic background, such as single nucleotide polymorphism, can have on the outcome of an injury. Current trends in diagnosis and drug development were discussed. Army Col. Jamie Grimes, MD, national director of the 
Defense and Veterans Brain Injury Center (DVBIC) introduced a session on military related neurotrauma. Keynote speakers for the three sessions were Andrew Maas, Thomas Carlstedt, and Jordan Grafman.

We are delighted to present a cross section of the presentations from the Karolinska anniversary symposium in this Research Topic and its associated book.
Received: 10 February 2012; accepted: 10 February 2012; published online: 24 February 2012. Citation: Risling M, Bellander B-M and Cullheim S (2012) Traumatic injuries in the nervous system. Front. Neur. 3:26. doi: 10.3389/fneur.2012.00026

This article was submitted to Frontiers in Neurotrauma, a specialty of Frontiers in Neurology. Copyright $\odot 2012$ Risling, Bellander and Cullheim. This is an open-access article distributed under the terms of the Creative Commons Attribution Non Commercial License, which permits non-commercial use, distribution, and reproduction in other forums, provided the original authors and source are credited. 